\title{
Analysis on Exchange and Cooperation of Universities in Fujian and Taiwan under the Background of Supply-side Structural Reform of Higher Education
}

\author{
Jianping Huang \\ Fuzhou University of International Studies and Trade \\ Fuzhou, China 350200
}

\author{
Lihua Huang \\ Fuzhou University of International Studies and Trade \\ Fuzhou, China 350200
}

\begin{abstract}
Current situation, applied transformation direction, living examples and strategies of exchange and cooperation of application-oriented universities in Fujian and Taiwan under supply-side structural reform of higher education are researched in this paper. It focuses on the strategy research to make for the smooth exchange and cooperation of universities in Fujian and Taiwan.
\end{abstract}

Keywords-higher education supply-side; Fujian and Taiwan; exchange and cooperation

\section{INTRODUCTION}

During the 13th five-year, our country is in the new normal of economic development. The demand-side and supply-side reform in the economic field plays an important role in guiding the supply-side structural reform of higher education. The "supply-side reform" is to realize reasonable coordination between supply side and demand side, in order to strengthen the continuous economic development. The adjustment of economic policies will inevitably influence the development of higher education.

Fujian province have close geographical relationship, intimate blood relationship and same cultural relationship, close commercial relationship and same law relationship with Taiwan and the unique advantages of exchange with Taiwan. The support of "Early and Pilot Implementation" for Fujian province in exchange across the straits is an important step to accelerate the construction of economic zone in the west coast of the Taiwan Straits, improve economic layout of coastal regions and strengthen strategic deployment of crossstrait exchange and cooperation. The improvement of exchange and cooperation level of applied universities in Taiwan and mainland and the integration of superior resources through cooperation in higher education can solve problems in exchange and cooperation of cross-strait economy and higher education. Therefore, the supply-side structural reform of higher education connects applied universities in Fujian and Taiwan with the society and provides directions for exchange and cooperation of them.

\section{DEFINITIONS OF CORE CONCEPTS IN EXCHANGE AND COOPERATION OF UNIVERSITIES IN FUJIAN AND TAIWAN UNDER SUPPLY-SIDE REFORM OF HIGHER EDUCATION}

\section{A. Supply-Side Reform of Higher Education}

At the beginning of 2015, the General Secretary Xi Jinping proposed the concept of supply-side structural reform, "the primary purpose of supply-side reform is to improve social productivity level and implement the peopleoriented development idea". The supply-side reform is applicable to economic and educational fields. It improves resource allocation and factor efficiency as well as education quality, optimizes educational structure and strengthens vigor of running schools as well as provides efficient higher education supply for the society. We should reasonably optimize resource allocation of higher education and improves the efficiency of basic factors in it, especially values people and system, in order to optimize training scale, hierarchical structure and professional discipline of higher education and realize the functions of it in the economic and social development at present.

\section{B. Higher Education Cooperation between Fujian and Taiwan}

Higher education cooperation between Fujian and Taiwan means universities in Fujian and Taiwan and Taiwan-funded enterprises sign cooperation agreements to cooperate in student management, specialty construction, course construction, teaching staff construction and textbook compilation.

Fund program: Planning project of the Ministry of Education supported by national education and science planning unit: Research on Exchange and Cooperation of Universities in Fujian and Taiwan under the background of Supply-side Structural Reform of Higher Education (FIB160490) 
III. BACKGROUND OF EXCHANGE AND COOPERATION OF UNIVERSITIES IN FUJIAN AND TAIWAN UNDER THE SUPPLYSIDE REFORM OF HIGHER EDUCATION

\section{A. Transformation Requirements in Supply-Side Reform of Higher Education}

In recent years, the higher education development in our country has achieved remarkable results, but the demandside reform leads to problems in structure, quality and efficiency of higher education. It avails the construction of main battlefield in transformation of higher education into applied undergraduate, effective explanation of necessity of applied undergraduate transformation and guidance of positive energy in universities of Fujian and Taiwan. Therefore, it realizes practice guidance on carrying forward the transformation of higher education reform.

Economic reform will inevitably drive educational reform. After the reform and opening up, the soaring economic development arouses people's requirements for higher education to train theoretical and academic talents. The talent training pattern fails to provide applied and innovative talents required by economic upgrade and industrial transformation. The vocational education in Taiwan has had mature experience in cultivating applied and innovative talents. Universities in Fujian and Taiwan have increasingly closer relationship. Therefore, the academic world can refer to successful experience of education in Taiwan to guide the transformation of universities in Fujian into application-oriented ones.

\section{B. Requirements of Higher Education Development in Taiwan}

The development experience of economy and society in Taiwan indicates with the improvement of industrial structure, especially the development of high-technology industry, numerous applied talents are required. After nearly fifty years of development, Taiwan has formed the vocational education system with integration of technical vocational colleges that train talents related to industrial technology, management and service, junior college, technical college and university of science and technology. Higher technical and vocational education above undergraduate in Taiwan appeared in the 1970s. From the middle and later periods of 1970 s to the 1990s, in order to improve the level of technical and vocational education and train high level talents for applied technology, the first technical college namely National Taiwan University of Science and Technology was founded in August 1974. After 1990, some technical colleges provide postgraduate education, class of master and doctor, and some are upgraded to university of science and technology. Especially since 1997, universities of science and technology and technical colleges (higher technical and vocational education) above undergraduate level in Taiwan have developed vigorously, becoming the main part of higher technical and vocational education and accumulating rich experience in training applied talents.
There are 34 (institutions) projects of cooperation in running schools between Fujian and Taiwan. The higher technical and vocational education above undergraduate level in Taiwan has trained excellent high level technologyapplied talents for economic construction and the society, has accumulated rich experience at government and school levels in training applied talents. The experience at government level includes implementing the strategy of education first, endowing universities with autonomy in running schools and valuing the legal construction of education. The experience at school level includes flexibly and independently providing new-type specialties urgently required by social and economic development, constructing mechanism of university-enterprise cooperation and valuing the training of teachers and the school-based course provision.

\section{C. "Early and Pilot Implementation" Policy Supports the Exchange and Cooperation of Universities in Fujian and Taiwan}

Some Opinions on Supporting Fujian Province to Accelerate the Construction of Economic Zone on the West Coast of the Taiwan Straits issued in May 2009 by the State Council positions Fujian province as the "pilot area for exchange and cooperation of people in Taiwan and mainland". How to implement the "Early and Pilot Implementation" policy for Fujian province and exploit the advantages of "five relationships" between Fujian and Taiwan is the key to promote the continuous exchange and cooperation in cross-strait education. It proposes in the Opinions on Implementation of Exchange and Cooperation in education of Fujian and Taiwan issued in October 2008 by the Education Department of Fujian province that "Fujian province will continuously expand the cooperation scope of cross-strait universities in discipline and specialty; focus on vocational education to promote university-enterprise cooperation and "university-university-enterprise" cooperation between Fujian and Taiwan and further promote the in-depth cooperation between Fujian and Taiwan in training applied talents; advance the mutual education certification and student exchange between Taiwan and mainland and send more students in Fujian to learn in Taiwan and enroll more students in Taiwan". The introduction of the Opinions provides policy guarantee to further promote the dominant position of Fujian province in the exchange with Taiwan.

In order to realize exchange and cooperation of universities in Fujian and Taiwan, in the construction of "pilot area for cross-strait exchange and cooperation", we should let higher education connect cross-strait people and strengthen the mutual understanding with higher education world in Taiwan through interschool exchange, personnel exchange, project cooperation and cultural integration between Fujian and Taiwan, and create a new situation for exchange and cooperation of applied universities in Fujian and Taiwan. 


\section{RESEARCH CONTENTS IN EXCHANGE AND} COOPERATION OF APPLIED UNIVERSITIES IN FUJIAN AND TAIWAN UNDER THE SUPPLY-SIDE REFORM OF HIGHER EDUCATION

In the exchange and cooperation of applied universities in Fujian and Taiwan, ideas and factors that influence it are proposed through investigation on it; guidance direction for applied transformation of it is proposed through research on it; experience in it is concluded through research on living examples in it; strategy researches are provided in enrollment scale, cooperation in running schools, mutual employment, evaluation and construction of teaching staff, scientific research cooperation and school size.

\section{A. Research Contents in Exchange and Cooperation of Applied Universities in Fujian and Taiwan under Supply-Side Reform of Higher Education}

1) Investigation on current situation of exchange and cooperation of applied universities in Fujian and Taiwan under supply-side reform of higher education

Interviewing method, questionnaire method and statistical analysis method are applied to research: (1) development status of applied universities; (2) excellent school-running experience and development status of applied universities in Taiwan.

2) Research on applied transformation in exchange and cooperation of universities in Fujian and Taiwan under supply-side reform of higher education

The guiding effect of research on exchange and cooperation of applied universities in Fujian and Taiwan under supply-side reform of higher education is proposed through analysis on current situation of exchange and cooperation and internal and external environment of supplyside reform of higher education, including: (1) realize the transformation of objectives and patterns in exchange and cooperation of applied talent training in higher education of Fujian and Taiwan from "theoretical, academic" to "technical, applied"; (2) realize the transformation of exchange and cooperation of scientific research in higher education of Fujian and Taiwan from "longitudinal" to "lateral"; (3) realize the transformation of social service in applied higher education in Fujian and Taiwan from "in name only" to "be worthy of the name".

3) Research on living examples of exchange and cooperation of applied universities in Fujian and Taiwan under the supply-side reform of higher education-take some researches in universities of Fujian and Taiwan as examples

Example illustration is carries out through empirical investigation and research. According to examples of exchange and cooperation in applied universities of Fujian and Taiwan in recent years, the direction of it is analyzed through extensive investigation, in order to improve the successful experiences of cooperation in running universities in Fujian and Taiwan.
4) Strategy research on exchange and cooperation of applied universities in Fujian and Taiwan under the supplyside reform of higher education

As a subsystem in economic and social area, higher education shoulders the responsibility of supply-side structural reform. In order to promote the supply-side structural reform, universities in Fujian provide effective, accurate and high quality supply in talent training, scientific research, social services, cultural inheritance and innovation and transform from demand side to supply side, and provide strategy research for applied universities in Fujian and Taiwan in enrollment scale, cooperation in running schools, mutual employment, evaluation and construction of teaching staff, scientific research cooperation and school size.

\section{B. Innovative Ideas in Exchange and Cooperation of Applied Universities in Fujian and Taiwan under the Supply-Side Reform of Higher Education}

Assuming applied universities in Fujian and Taiwan can cooperate smoothly under supply-side structural reform of education, we conclude the following innovative ideas:

\section{1) Academic idea innovation}

Supply-side reform is taken as the most important support. Economic reform will inevitably promote educational reform and development. The exchange and cooperation of universities in Fujian and Taiwan conforms to trend of the times and explains the necessity and urgency of supply-side reform of higher education and exchange and cooperation of applied universities in Fujian and Taiwan. Moreover, Dewey's pragmatic education provides another important theoretical support. "Education refers to the continuous transformation of experience" summarizes the nature of education. The analysis on necessity and feasibility of exchange and cooperation in applied universities under supply-side reform of higher education through this theory is persuasive. On the whole, the application of basic theories has innovative significance in analysis and research on exchange and cooperation of applied universities in Fujian and Taiwan under the supply-side reform of higher education.

\section{2) Academic view innovation}

Compared with the exchange and cooperation of universities in the world, the research on exchange and cooperation of universities in Fujian and Taiwan is at the initial stage. Previous researches on exchange and cooperation of universities in Fujian and Taiwan are superficial. It is representative and has demonstration effect to research the exchange and cooperation of it.

\section{CONCLUSION}

In conclusion, the analysis on exchange and cooperation of universities in Fujian and Taiwan under supply-side structural reform of higher education avails the determination of research contents in it and guarantees smooth implementation of the research. 


\section{REFERENCES}

[1] Yang Weijian. Development Path for Higher Education in Fujian under the Supply-side Structural Reform [J], Journal of Putian University [J], 2012(06): 89-93

[2] He Fen. Development Path for Higher Education in Fujian under the Supply-side Structural Reform, Education Review [J], 2016(12): 9-13

[3] Mo Yuwan. Current Situation and Outlook of Cooperation in Running Schools between Fujian and Taiwan [J], Journal of Minxi Vocational and Technical College, 2013(09): 60-65. 